\title{
Accountants bij de politie?
}

\author{
Jaap van Manen
}

In 1994 woeg ik aan een groep studenten die waren voorbestemd om in het cursusjaar 94195 het accountantsexamen te doen, waar zij dachten te werken over respectievelijk tien en twintig jaar. Dat leidde tot het volgende overzicht (1994 geeft, ter vergelijking, de werkelijkheid aun):

\begin{tabular}{|c|c|c|c|}
\hline & 1994 & 2004 & 2014 \\
\hline Big 6-kantoor & 29 & 2 & 0 \\
\hline Middelgroot kantoor & 7 & 4 & 0 \\
\hline \multirow[t]{2}{*}{ Klein kantoor ( $\left.\leq 20 \mathrm{RA}^{\prime} \mathrm{s}\right)$} & 2 & 5 & 6 \\
\hline & 38 & 11 & 6 \\
\hline \multirow[t]{2}{*}{ Interne accountantsdienst } & 3 & 3 & 0 \\
\hline & 41 & 14 & 6 \\
\hline Bedriffsleven & 4 & 28 & 33 \\
\hline Overheid & 3 & 3 & 4 \\
\hline Not for profit & $l$ & 4 & 5 \\
\hline Ondernijs & I & 1 & I \\
\hline \multirow[t]{2}{*}{ Overig } & 0 & 0 & I \\
\hline & 50 & 50 & 50 \\
\hline
\end{tabular}

Als werkkringaanduiding had ik niet opgenomen politie. Voor de studenten was dat ook geen gemis: ik had ze gevraagd of het overzicht van mogelijke werkkringen wat hen betreft volledig was. Toch is er volgens mij voor accountants veel te doen bij de politie. Daarop wijst de opkomst van afdelingen forensic accounting en antifraudedesks bij grote accountantskantoren. De IRT-enquêteverhoren leerden ons dat er ook nog wel wat problemen waren op het vlak ran interne controle, op door de politie afgesloten drugstransacties bijvoorbeeld. Daarnaast kunnen we zien dat de opkomst van de georgani- seerde misdaad een bijzonder beroep doet op voor generalistische politienensen nieuwe kennis en kunde. De 'pluk ze'-wetgeving, verschijnselen als crimineel geld, de vermoedelijke penetratie van criminelen in overheid en bedrijfsleven, corruptie, subsidiefraudes, belastingontduiking betekenen dat het politiewerk voor accountants zeer aantrekkelijk kan zijn. Maar, sprekend met studenten, kunnen w'e ook dichter bij huis blijven: een serieuze aanpak van fietsendiefstal vraagt mijns inziens ook om een accountantsachtige benadering.

Fietsendiefstal zit enerzijds in de hoek van de kleine ongeorganiseerde misdaad: een dronken student breekt bijvoorbeeld een slor open van de fiets van een slapende student die daardoor de rolgende ochtend een college (over ethiek?) moet missen en zich wellicht genoodzaakt ziet om de schade op een andere student te verhalen door zelf ook een fiets te stelen. Anderzijds is er de wel georganiseerde misdaad: fietsen worden gestolen en vervolgens getransporteerd naar een andere stad, waar zij worden verkocht aan mensen waarvan de fiets zojuist wellicht door dezelfde organisatie is gestolen. Nu kan men fietsen alleen maar verkopen als men ze aanbiedt: met een advertentie in een krant. door middel van een advertentic op een prikbord, wellicht via Internet of op wat voor manier dan ook. Dat wat potentiële fietsenkopers kumnen lezen is ook toegankelijk voor opsporingsambre-

Prof. Drs. J.A. van Manen is vennoot bij de maatschap Coopers \& Lybrand en hoogleraar Accountantscontrole aan de Rijksuniversiteit Groningen. 
naren: die hoeven alleen maar op overvalsmomenten na te gaan wat de identiteit is van de aangeboden fietsen (geen probleem gezien het tegenwoordig in zwang zijnde systeem van graveren en registreren). Uit de administratie (in het bijzonder wit het opkopingsregister) van de betreffende fietsenhandel zal bovendien blijken waar de betreffende fiets vandaan komt. Hoogstwaarschijnlijk is het wel noodzakelijk op het punt ran het opkopingsregister en van de financiële administratie nadere vorschriften uit te vardigen. Het lastigste probleem zal blijven de volledigheid ran het opkopingsregister: een typisch accountancy-1raagstuk.

Modern politiewerk houdt in het bestrijden van misdrijuen. De aandacht is niet primair gericht op het aantal opgeloste misdrijven. Structurele terugdringing van de misdaad is het primaire doel. Dat betekent dat naast het oplossen van gesignaleerde criminaliteit een grondige analyse van die criminaliteit plaatsvindt, zodat maatregelen ter voorkoming van misdrijven kummen worden genomen. Daarbij gaat het in reel gevallen om preventie door betere controle. En controle dat is iets, waarin accountants een bijzondere scholing hebben gehad. Vanuit hun deskundigheid kunnen zij veel bijdragen aan een structureel terugdringen van de misdaad. Dat de deskundigheid van anderen daarbij niet gemist kan worden spreekt voor zich. In het voorbeeld van de fietsendiefstal zijn juristen nodig om zich te buigen over eventuele noodzakelijke wetswijzigingen terzake van de handel in tweedehands rijwielen.
Dit alles neemt niet weg dat de politiekorpsen in Nederland behoefte hebben zowel aun jonge als aan ervaren accountants. Gelukkig voor hen zitten accountants niet vastgebakken aan hun oorspronkelijke metier. Het bovenstaande schema is daarvan een goede illustratie. Accoumtants die andere wegen hehben bewandeld dan die van de controle van de jaarrekening zullen daarvan warschijnlijk ook niet vaak spijt hebben. De hoogste baas zijn van een grote oliemaatschappij of van een financieel conglomeraat is natuurlijk niet iedere accountant gegeven, mat het carrièreperspectief voor registeraccountants buiten de accountancy mag er zijn. Dat carrièreperspectief ontbreekt overigens nog bij de politiekorpsen in ons land. Zonder een ingrijpende wijziging in het belcid wordt het voorlopig nog niet mogelijk voor registeraccountants om bij de politie te gaan functioneren op een niveau dat vergelijkbaar is met dat van een korpschef. Wellicht dat de discussie die $m$. mede naar aanleiding van de IRTkwestie. rond de organisatie van de politie platsvindt kan leiden tot een klimaat waarin dat wel mogelijk is. Dan gaat het echter om veel meer dan alleen de positie van registeraccountants bij de politie: de gewenste vooropleiding van politieofficieren in het algemeen kan dan nog eens worden heroverwogen. Ik hoop dat de uitkomst daarvan zal zijn dat er meer ruimte komt voor academici: juristen, sociologen, economen, registeraccountants en nog vele anderen. Misschien komt er zelfs nog wel eens een postdoctorale politieopleiding. Maar voordat we dat bereikt hebben zullen er nog heel reel fietsen gestolen worden. 